and grow as it should do. The key sentence in Dr. Allen's letter is, "Further finance must be made available." The key fact of life in Britain in the 1960s is that not much further finance for such expansion is going to come from the Treasury. Where is it going to come from? Directly from the pockets of the public is the only answer, highly unpalatable though this answer is. Having paid heavily already in income tax and National Insurance contributions for the benefits of the welfare state, the public are not going to like dipping their hands into their own pockets to pay yet more. But if expansion is needed and the Treasury chests are locked, it is the only way.

I have already started by improving my surgery and doubling my charge for private certificates from $1 \mathrm{~s}$. to 2s. Let the hospitals do the same-build up amenity funds and seek voluntary sources of income as in the old days. Have Hospital Saturday Funds which will help to provide amenity beds. Get the voluntary moneys rolling in, publish the accounts, and show the public that the money is spent on improvements and facilities they can appreciate.-I am, etc.,

London E.C.1.

J. G. BANCROFT.

\section{Better General Practice}

SIR,-I find it interesting that a colleague in general practice (Dr. R. E. Faulkner, February 16, p. 469) should think that the 20th-century G.P. should be content to practise medicine with only the twin arts of history-taking and physical examination to help him. While I agree entirely that these two arts are still the foundation of all good practice, surely we should not be content that all branches of medicine except general practice should benefit from the diagnostic aids which are now available.

$\mathrm{He}$ also evidently considers that he gets sufficient professional contact with his colleagues by way of domiciliary consultations. I can only conclude that he conducts an abnormal amount of them or that he is too easily satisfied in this respect.

I am fortunate in being in practice in an area where the G.P. is made welcome at postgraduate ward rounds ; and I must admit that it was only when I started attending these that I became aware of how much I had been missing by losing all contact with hospital practice. But, inspiring as these ward rounds are, they can never be a substitute for having clinical responsibility for hospital patients. A spectator can never learn as much as a player about the game. I think the greatest gain a G.P. would derive from part-time hospital employment would be the intellectual stimulation from discussing cases with colleagues in hospital. This would serve to keep him up to date and interested in his job, and enable him to give a better service to his domiciliary patients. The very high standard of general practice which exists in those parts of North America where G.P.s have hospital appointments lends weight to this view. Judging by the amount currently being written about the future of general practice, the topic looms large in the minds of medical teachers and administrators, and the evolution of the G.P. in this country would appear to have reached a crucial stage. Some writers have implied that something less than the "doctor" as we know him could carry out adequately the duties of the G.P. as they exist in the U.K. to-day; and the great differential that exists in payment and prospects between the specialist and the G.P. gives a better indication than words could of how our employers rate the value of our services. And having regard to the limited scope and nature of those services, can we honestly say that the authorities have grossly undervalued them ?

I think we were trained for better things and that our capabilities should not largely be wasted in trivial drudgery. We should be given more responsibility, more diagnostic facilities, hospital beds, and more pay. More doctors would have to be employed and lists would have to be reduced in size.

Sir, I am convinced that part-time hospital employment is the solution to our difficulties, the only way to raise our status and give us the opportunity to give the type of service which would not only be more satisfying to ourselves but also to the community which we serve. -I am, etc.,

Belfast 5.

J. D. H. MAHONY.

\section{Eczema and Cows' Milk}

SIR,- - The effects of allergy to cows' milk are dramatic and serious but the affection is fortunately very rare in this country. The symptoms are usually those of collapse, gastro-intestinal upset, urticaria, anaemia, and failure to thrive. Cases described have not usually been associated with eczema. ${ }^{12}$

The statement in your annotation (March 2, p. 561) that "it has for long been known that infantile eczema may be caused by sensitization to the proteins of cows' milk" is, to say. the least, unfortunate. We doubt whether infantile eczema is ever due, specifically, to cows' milk or to any other food. We have repeatedly failed to confirm the suggestion that milk-free diets or goats' milk substitution would cure the condition and we do not find any convincing evidence in the literature. ${ }^{3}$

Reaction to skin tests with foods and more elaborate immunological tests are not of diagnostic value in infantile eczema and are misleading. The clinical impressions of therapeutic dietetic tests in this field are not valid evidence. It is harmful and, we think, undesirable to create anxieties in the minds of the worried parents of eczematous children by suggesting that the diet is responsible.-We are, etc., Department of Dermatology,
University of Durham.

JOHN T. INGRAM.

G. Holti.

REFERENCES

Bower, B. D., Stanley-Roose, D. G., and Wolff, O. H., Brit. med. J., 1958, 2, 195

' Vendel, S., Acta paediat. (Uppsala), 1948, 35, suppl. 5, 1.1202.

\section{Diabetes Mellitus and Pernicious Anaemia}

SIR,-I apologise to Dr. J. F. Wilkinson (March 9, p. 676) that in our paper on diabetes mellitus and pernicious anaemia (January 19, p. 159) we should inadvertently have included his results in a general criticism of retrospective surveys. Dr. Wilkinson has, of course, been a pioneer of prospective surveys in this country. In extenuation I can only say that we have stimulated him to write a most interesting and valuable letter on the association of pernicious anaemia with diabetes and thyroid disease.-I am, etc.,

Radcliffe Infirmary, Oxford.

L. J. WitTs.

Correction.-We are asked by Dr. W. H. Beasley to state that in his letter "Cancer in North Wales" (February 23, p. 542) be inadvertently transposed the percentages. The figure $69.71 \%$ should read $75.57 \%$ and vice versa. The figure $30.29 \%$ should read $24.33 \%$ and vice versa. 